\title{
Role of hydrogen and fuel cells in renewable energy systems
}

\author{
Sørensen, Bent
}

Published in:

World Renewable Energy Congress VI

Publication date:

2000

Document Version

Publisher's PDF, also known as Version of record

Citation for published version (APA):

Sørensen, B. (2000). Role of hydrogen and fuel cells in renewable energy systems. In A. Sayigh (Ed.), World Renewable Energy Congress VI (pp. 1469-1474). Pergamon Press.

\section{General rights}

Copyright and moral rights for the publications made accessible in the public portal are retained by the authors and/or other copyright owners and it is a condition of accessing publications that users recognise and abide by the legal requirements associated with these rights.

- Users may download and print one copy of any publication from the public portal for the purpose of private study or research.

- You may not further distribute the material or use it for any profit-making activity or commercial gain.

- You may freely distribute the URL identifying the publication in the public portal.

\section{Take down policy}

If you believe that this document breaches copyright please contact rucforsk@kb.dk providing details, and we will remove access to the work immediately and investigate your claim. 


\title{
ROLE OF HYDROGEN AND FUEL CELLS IN RENEWABLE ENERGY SYSTEMS
}

\author{
BENT SØRENSEN*
}

\author{
Roskilde University, Energy \& Environment Group, PO box 260, DK-4000 Roskilde, Denmark \\ email: bes@ruc.dk, web: httl://mmf.ruc.dk/energy
}

\begin{abstract}
The special requirements of fluctuating renewable energy sources include storage, backup or import/export arrangements. This paper will focus on the possible role of hydrogen as an energy carrier in an energy system with large contributions from renewable energy sources such as wind power or solar electricity. In particular, it will be shown that the structure of the transportation sector may develop in such a way, that the renewable energy and hydrogen type of solution becomes particularly attractive. This involves fuel cell driven vehicles and technology for introducing infrastructure changes at a minimum cost.
\end{abstract}

\section{KEYWORDS}

Renewable energy; hydrogen, energy storage, fuel cells, wind power, solar electricity.

\section{CHARACTERISTIC TIME-PATTERNS OF RENEWABLE ENERGY PRODUCTION}

The nature of the problem addressed follows from the time-sequences of solar energy and wind power shown in Figs. 1 and 2. The output from a solar energy device (Fig. 1) will have strong diurnal variations, as well as strong seasonal variations, with a growing amplitude the further away from the Equator the equipment is operating, and despite choosing the optimum inclination angle for collector panels. For wind power, there are only minor diurnal variations (associated with the sunset and sunrise disturbance of the atmosphere), but large variations with passing weather fronts, the passage times of which over a particular location ranges from hours to weeks. Additionally, there are fluctuations on a shorter time scale due to turbulence, which can be noted in Fig. 2 (cf. Sørensen, 2000).

\section{MODELS OF HYDROGEN ENERGY STORAGE AND USAGE}

There are two ways of introducing hydrogen in a developing energy system with high dependence on renewable energy sources (both storable ones such as biogas and biofuels, and those which requires separate types of storage, such as solar heat or electricity, and wind power). One, which shall be denoted "centralised", uses electricity to produce hydrogen by conventional electrolysis or by reverse fuel cell "electrolysers". This hydrogen may be stored in compressed form centrally, in containers, excavated salt caverns or rock stores, or it may be stored more decentralised, in metal hydride systems or carbon nanotubes (Sørensen, 1998). The trans- 
Global solar radiation, Skjern Denmark, 1. half of 1995

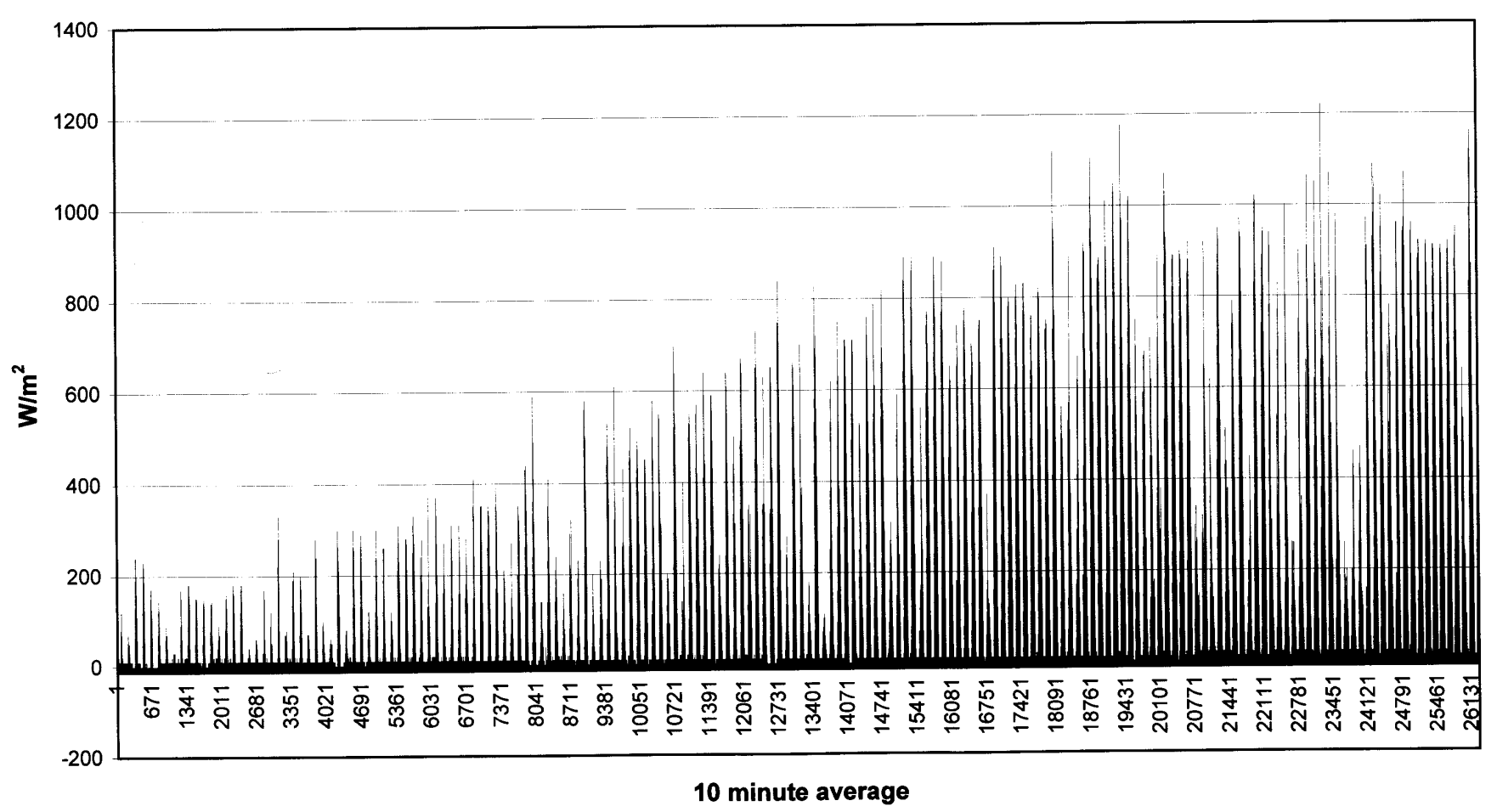

Fig. 1. One half year of 1995 global solar radiation data for Skjern in Western Denmark. (W/m² on a horizontal plane, given at 10 minutes intervals), as constructed from Ris $\emptyset$ data (1997).

Wind turbine power output at Vindeby 1995, hubheight 48m

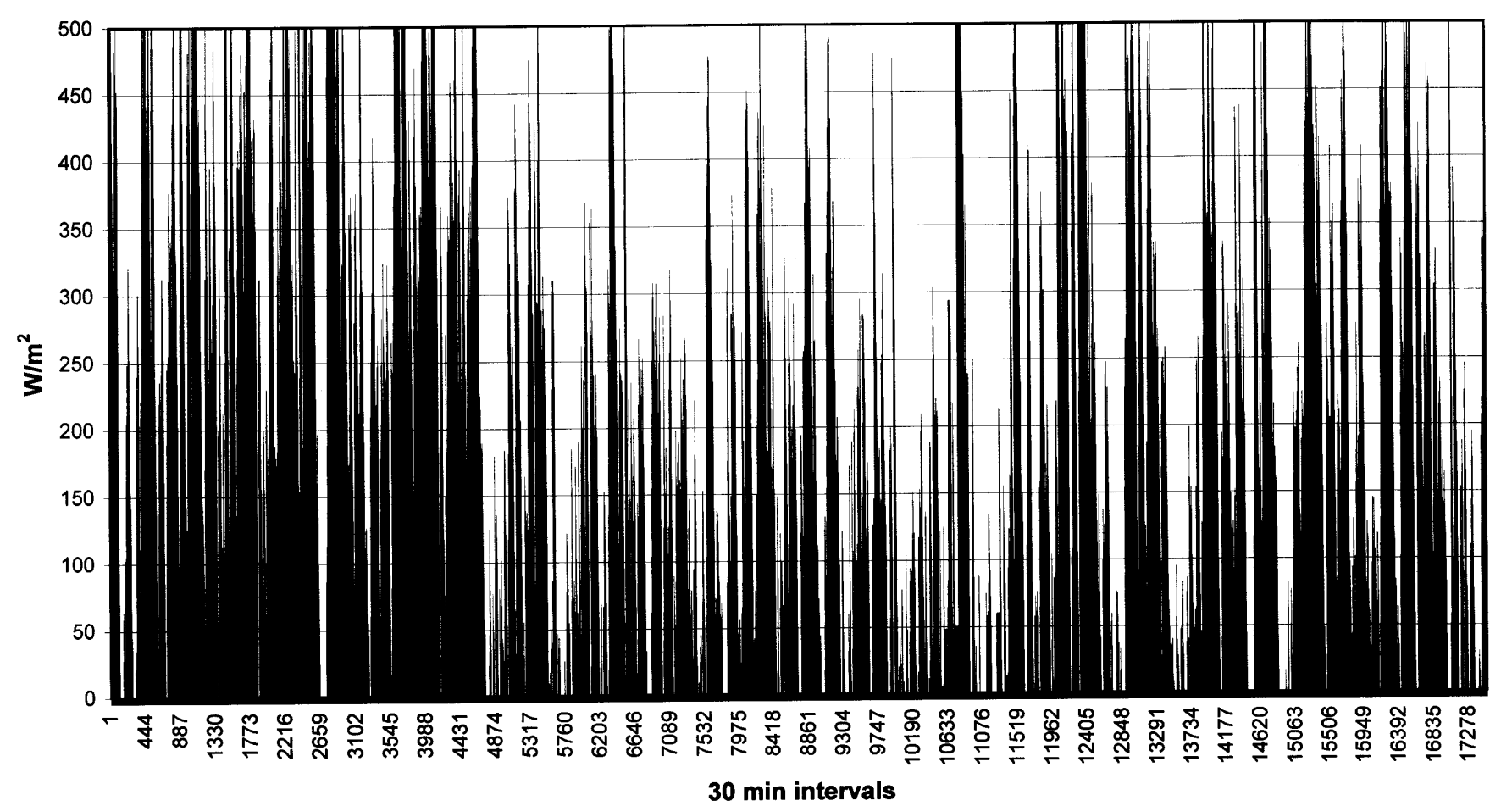

Fig. 2. Power produced in 1995 at the Vindeby (South Denmark) off-shore wind site, from turbines with power characteristics rising linearly from 0 to $500 \mathrm{~W} / \mathrm{m}^{2}$ between 5 and $15 \mathrm{~m} / \mathrm{s}$ wind speeds, and then staying at $500 \mathrm{~W} / \mathrm{m}^{2}$ for higher wind speeds (as calculated from a consolidated time series constructed on the basis of raw data from Ris $\varnothing, 1997)$. 
mission of hydrogen will need a pipeline system of high quality, perhaps obtained by upgrading existing natural gas pipelines (Sørensen et al., 2000), and distribution to users in the transportation sector may be through modified petrol filling stations (Sørensen and Sørensen, 2000). Additional users may include industrial users of hydrogen for process heat, or power plants using hydrogen in gas turbines to produce electricity when the renewable energy based production online is insufficient. Fig. 3 schematically illustrates the components of such a system. The advantage is that road vehicles will be fuelled using the same infrastructure as today (filling stations). As a corollary, Fig. 5 shows the areas in Denmark currently served by natural gas infrastructure.

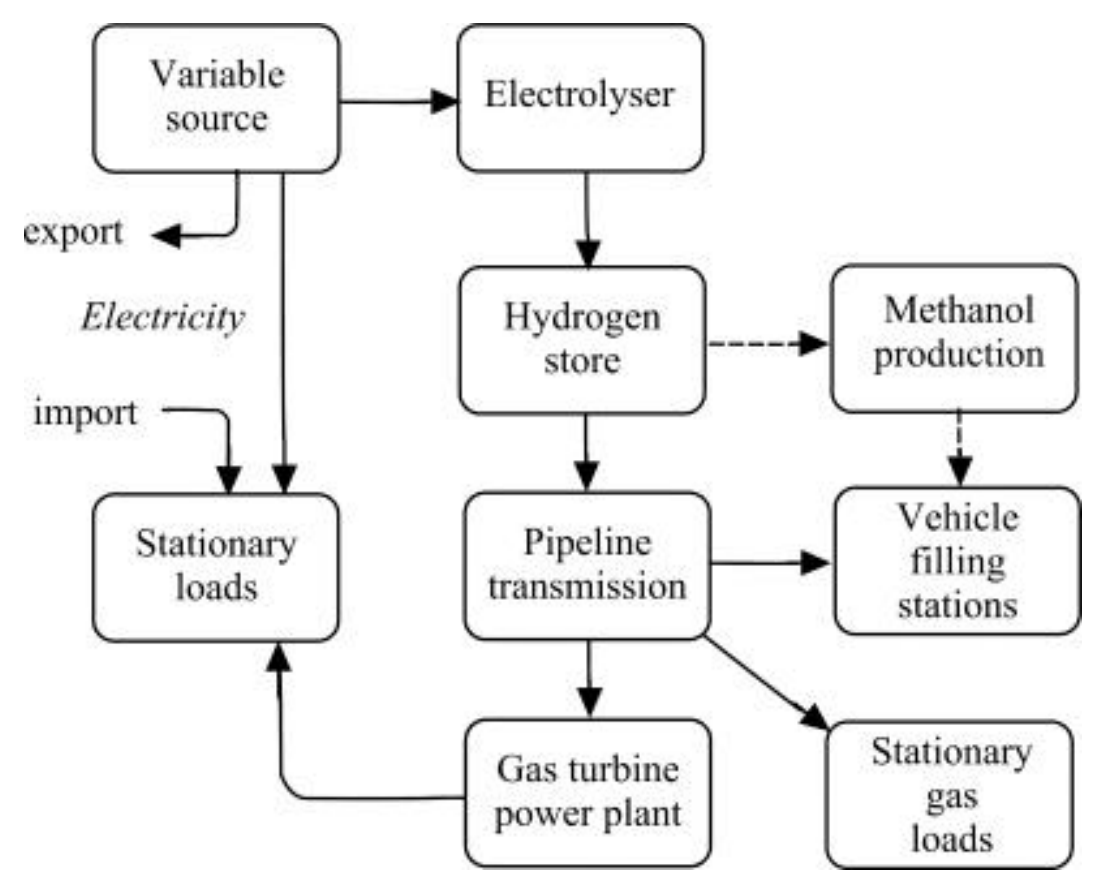

Fig. 3. Structure of centralised renewable energy system with hydrogen as an energy carrier.

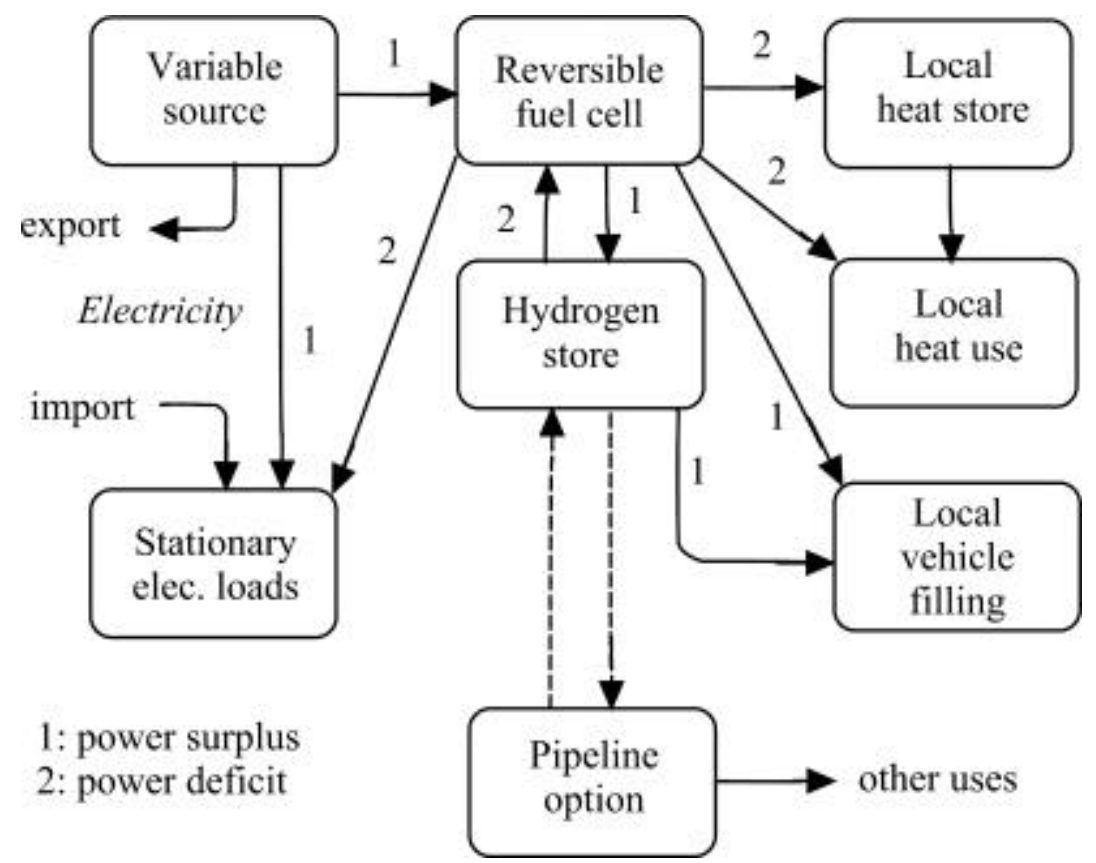

Fig. 4. Decentralised hydrogen and fuel cell based system for use with renewable energy inputs.

The other hydrogen system may be denoted "decentralised", in that individual producers can be any size down to owners of individual buildings, using reversible fuel cells as their main energy conversion tool. In contrast to the high-temperature fuel cells that may be used at power plants as an alternative to gas turbines, these would be a version of the PEM (proton exchange membrane) fuel cells currently undergoing rapid development with 
the aim to introduce them in vehicles for road transportation. In the present case, they would preferable be reversible, i.e. that they accept surplus electricity (at times of high wind or solar power production) as a source for producing hydrogen, but also hydrogen (at times of insufficient solar or wind power production) as a source for producing electricity and associated heat that may be used for space heating and other low-temperature heat purposes (such as hot water). It may be possible to store the hydrogen locally, using metal hydrides or perhaps in a longer time perspective carbon nanotube stores, as these exhibit excellent safety features and avoid the risks associated with storing hydrogen in compressed form. This is illustrated in Fig. 4. The hydrogen can be used to fuel the owner's motor cars and other vehicles at the building, as an alternative to charging electric batteries overnight with the surplus electricity. The weight of batteries makes electric vehicles with batteries suited only for urban use, whereas electric vehicles with hydrogen may presumably be used in the same way as the current gasoline-based cars. In this sense, the whole energy system becomes highly decentralised. Only in case the local storage capacity is insufficient (a possibility more likely to occur for solar cell based systems then for wind power systems, as indicated by Figs. 1 and 2), would a connection to a country-wide hydrogen gas transmission and distribution pipeline network be required. However, it may still be included in the system, in order to improve the supply security under conditions of local system repair and other failure.

\section{THE ROLE OF HYDROGEN STORAGE AND INFRASTRUCTURE}

Figs. 6 and 7 shows the wind power production of Fig. 2, averaged over each day or over an entire month. This illustrates the smoothing that may be obtained by short-term and larger storage capacities. The average production is well correlated with demand, being larger during winter but by less than a factor two.

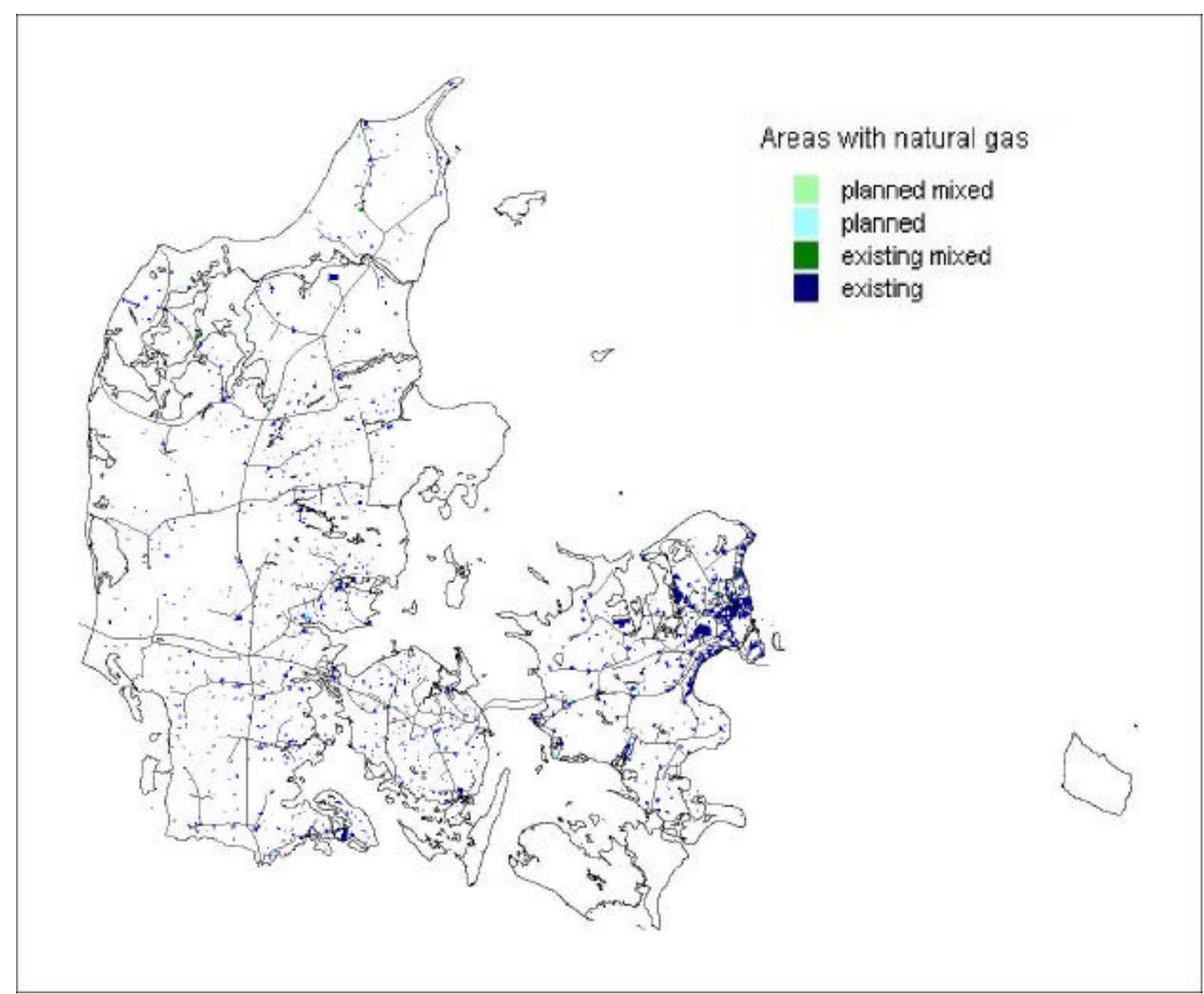

Fig. 5. Location of current main natural gas transmission lines in Denmark, and the areas served by gas distribution lines. These would be the areas that might get access to hydrogen through an upgraded gas network (Sørensen et al., 2000), 
Vindeby daily power output averages

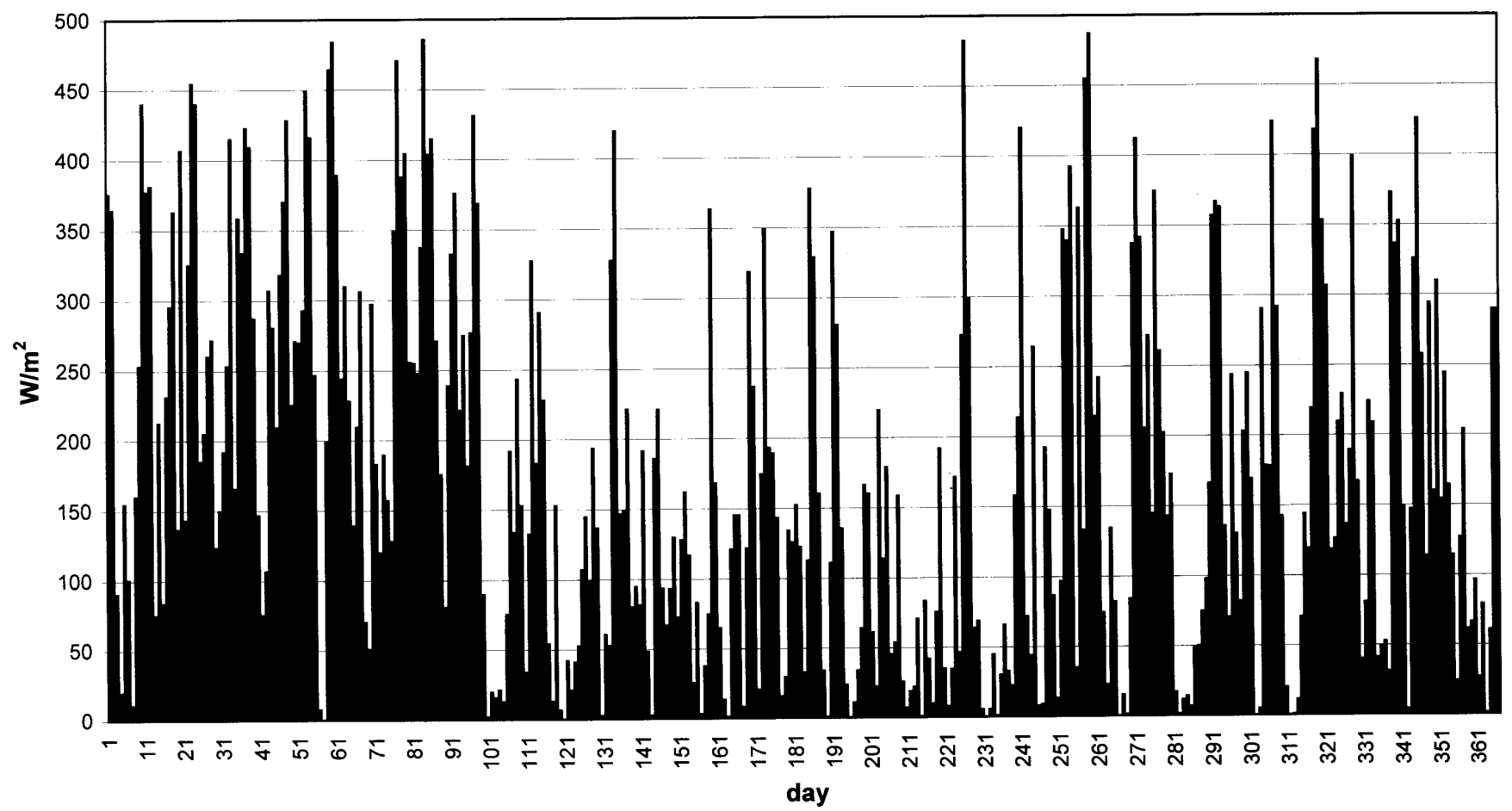

Fig. 6. Power produced in 1995 at the Vindeby off-shore wind site, averaged over each day of the year (see also details given in caption to Fig. 2).

Vindeby monthly power output averages

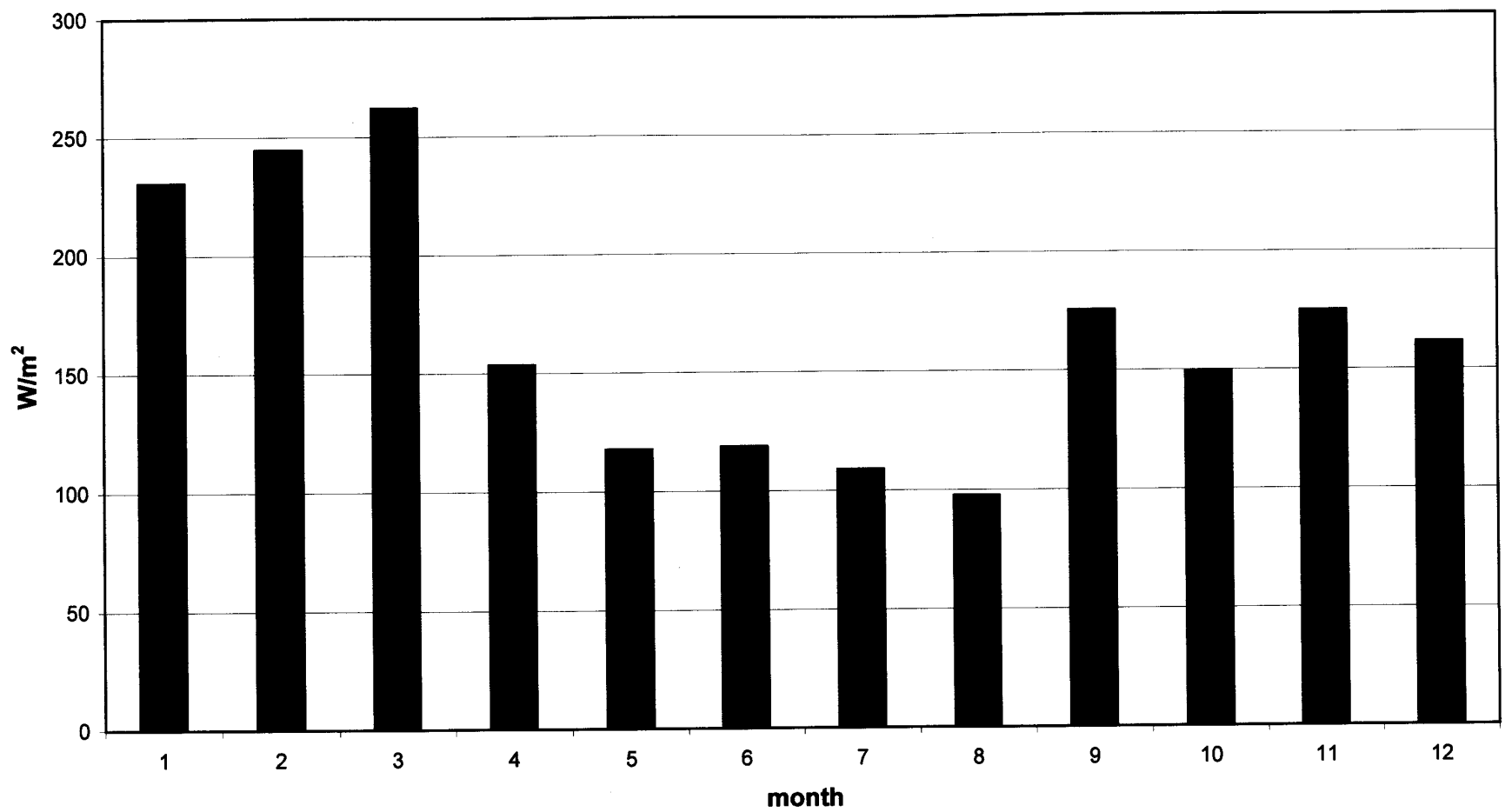

Fig. 7. Power produced in 1995 at the Vindeby off-shore wind site, averaged over each month of the year (see also details given in caption to Fig. 2). 


\section{DISCUSSION}

The ingredients for a renewable energy and hydrogen future have been outlined. In an ongoing project, the detailed geographical infrastructure constraints of the proposed models are discussed on the basis of scenario construction and simulation studies for Denmark (Sørensen, et al., 2000). Both the centralised and the decentralised scenario have distinct advantages, which are difficult to weigh against each other. However, the general development in society goes towards more decentralised solutions, and provided costs of items such as PEM fuel cells and compact hydride stores do come to fulfil expectations, this scenario stands a good chance of being considered politically, at least in countries such as Denmark, that already have ambitious renewable energy goals aimed at fulfilling greenhouse gas reduction targets.

\section{ACKNOWLEDGEMENT}

Part of the work described here is supported by the Danish Energy Agency under contract 1763/99-0001 of its hydrogen programme.

\section{REFERENCES}

Risø (1997). Raw data on wind speeds from Vindeby and several land-based sites, a few of which with solar radiation data, purchased from Risø National Laboratory.

Sørensen, B. (1998). Brint - et dansk perspektiv. Strategy note from the Hydrogen Council of the Danish Energy Agency, Copenhagen.

Sørensen, B. (2000). Renewable Energy (2nd Edition). 900 pp. Academic Press, London (1st Edition appeared in 1979).

Sørensen, B. and Sørensen, F. (2000). A hydrogen future for Denmark. Paper for "Hydrogen 2000 Conference, Beijing"

Sørensen, F., Sørensen, B., Petersen, A., Pedersen, T., Ravn, H., Simonsen, P., Jørgensen, K., Schleisner, L. and Morthorst, P. (2000). Scenarios for the utilisation of hydrogen as an energy carrier in the future energy system in Denmark. Contribution to this conference. A more detailed Progress Report (in Danish) for the project performed for the Danish Energy Agency, is available at our website http://mmf.ruc.dk/energy under Reports. 